\title{
Association of Exosomal miR-210 with Signaling Pathways Implicated in Lung Cancer
}

\author{
Qiaoyi Chen * and Xiaoge Xie \\ Department of Cell Biology and Genetics, School of Basic Medical Sciences, Xi'an Jiaotong University, \\ Xi'an 710049, China; xiexiaoge@snnu.edu.cn \\ * Correspondence: qychen203@xjtu.edu.cn; Tel.: +86-173-9255-0801
}

check for updates

Citation: Chen, Q.; Xie, X.

Association of Exosomal miR-210 with Signaling Pathways Implicated in Lung Cancer. Genes 2021, 12, 1248. https://doi.org/10.3390/genes12081248

Academic Editors: Edoardo Alesse,

Francesca Zazzeroni and

Alessandra Tessitore

Received: 8 July 2021

Accepted: 5 August 2021

Published: 16 August 2021

Publisher's Note: MDPI stays neutral with regard to jurisdictional claims in published maps and institutional affiliations.

Copyright: (c) 2021 by the authors. Licensee MDPI, Basel, Switzerland. This article is an open access article distributed under the terms and conditions of the Creative Commons Attribution (CC BY) license (https:// creativecommons.org/licenses/by/ $4.0 /)$.

\begin{abstract}
MicroRNA is a class of non-coding RNA involved in post-transcriptional gene regulation. Aberrant expression of miRNAs is well-documented in molecular cancer biology. Extensive research has shown that miR-210 is implicated in the progression of multiple cancers including that of the lung, bladder, colon, and renal cell carcinoma. In recent years, exosomes have been evidenced to facilitate cell-cell communication and signaling through packaging and transporting active biomolecules such as miRNAs and thereby modify the cellular microenvironment favorable for lung cancers. MiRNAs encapsulated inside the lipid bilayer of exosomes are stabilized and transmitted to target cells to exert alterations in the epigenetic landscape. The currently available literature indicates that exosomal miR-210 is involved in the regulation of various lung cancer-related signaling molecules and pathways, including STAT3, TIMP-1, KRAS/BACH2/GATA-3/RIP3, and PI3K/AKT. Here, we highlight major findings and progress on the roles of exosomal miR-210 in lung cancer.
\end{abstract}

Keywords: micro-RNA; miR-210; exosomes; lung cancer

\section{Introduction}

Over the past few decades, tremendous strides have been made in understanding the genetics and treatment of lung cancer. However, lung cancer remains the prevailing cause for global cancer-related morbidity and mortality [1]. Lung cancer is classified into two histological subtypes: non-small cell lung cancer (NSCLC) and small cell lung cancer (SCLC) [2]. NSCLC, which includes adenocarcinoma, squamous cell carcinoma, and large cell carcinoma, is the most prevalent, covering approximately $80 \%$ of all lung cancer cases [3]. SCLC is less commonly found (15-20\%) but is known to proliferate and metastasize more rapidly than NSCLC. In addition to these two main types, rare lung tumors such as carcinoid tumors, adenoid cystic carcinomas, sarcomas, and benign hamartomas have also been reported. Despite a wide array of currently available treatment methods including surgery, radiotherapy, chemotherapy, and immunotherapy, the 5-year survival rate of lung cancer patients is still under 20\% [4]. Poor disease prognosis is in part due to limited understanding of the complex nature of lung tumor heterogeneity as well as late disease presentation and diagnosis. Notably, cancers are known to have long incubation periods ( 20 years), during which time, the sensitivity of typical detection methods such as ultrasound, x-ray-based computer tomography, and endoscopy are inept. In recent years, liquid biopsy has become a widely used technique in clinical settings due to its ease of use, minimal invasiveness, and low cost. Most important, genomic information, such as global gene expression dysregulation, extracted from biofluids provide higher accuracy for disease detection as well as insights for underlying mechanisms of disease pathogenesis.

Aberrant expression of microRNAs (miRNAs) has been well-documented in lung cancer. Elevated oncogenic or reduced tumor suppressive miRNAs are equally important in altering cancer-related signaling pathways, and have been implicated in tumor cell growth, angiogenesis, and metastasis. In body fluids, miRNAs exist as circulating Ago 
protein-bound forms that are either released from damaged and dead cells or selectively packaged into extracellular vesicles (EVs) for cell signaling purposes [5-7]. Exosomes have been evidenced to play an important role in mediating cell-cell communication through transferring and depositing active biomolecules such as miRNAs, thereby eliciting epigenetic changes in recipient cells. Various exosomal miRNAs are dysregulated in lung cancer. In particular, miR-21, miR-31, and miR-192 are most commonly found in human lung cancer tissues and blood samples [8-11]. Through a comprehensive literature search, we find that aberrant expression of exosomal miR-210 is found across various human, cell, and animal models of lung cancer, indicating an important role in cancer development. MiR210 is a peculiar miRNA; apart from various cancers, its dysregulation is also associated with other human diseases such as cardiovascular disease and diabetic obesity [12,13]. What is more interesting is that its inclusion in exosomes in response to hypoxia is also relevant in placental disorder preeclampsia [14]. This review aims to examine the role of exosomal miR-210 in lung cancer and its potential underlying pathways.

\section{Biogenesis and Function of miRNAs}

MiRNAs are a group of endogenous non-coding RNAs approximately 22 nucleotides in length, and mainly function to mediate post-transcriptional gene silencing by binding to complementary sites in the $3^{\prime}$ untranslated region (UTR) of target mRNAs. Processing of miRNA can happen post- or co-transcriptionally $[15,16]$. Intragenic miRNAs are generated mostly from introns of protein coding genes, while intergenic miRNAs, located between genes, are processed by their own RNA polymerase II or III promoters [17]. MiRNAs are known to have short seed regions, approximately seven nucleotides, that are often found to be similar to a multitude of other miRNAs. In general, miRNA can be processed through either canonical or non-canonical pathways $[16,18,19]$. Non-canonical miRNA biogenesis includes Dicer-independent and Drosha/DGCR8-independent pathways. PremiRNAs produced such as mirtrons often resemble Dicer substrates. In the canonical pathway, the dominant pathway, pri-miRNAs transcribed by RNA polymerase II are first cut into pre-miRNAs by microprocessor complex, which consists of RNA binding protein DiGeorge Syndrome Critical Region 8 (DGCR8) that recognizes pri-miRNA motifs, and Drosha, a ribonuclease III enzyme responsible for cleaving the pri-miRNA duplex, leaving a $3^{\prime}$ overhang [20,21]. Lastly, pre-miRNA is transported to the cytoplasm via exportin 5 (XPO5)/RanGTP complex, where the terminal loop is removed by RNase III endonuclease Dicer, resulting in mature miRNA duplex [22]. The double helix is then unwound by helicase into either $3 p$ or $5 p$ strands. The $3 p$ strand originates from $3^{\prime}$ end of the premiRNA hairpin, and $5 p$ strand comes from the $5^{\prime}$ end. While both strands can be loaded into Argonaute (AGO) and serve as the guide strand, the preferred strand is often the one with the lower $5^{\prime}$ thermodynamic stability, mostly with uracil at the $5^{\prime}$ end. The leftover or passenger strand will then be eliminated by AGO-related degradation mechanisms.

MiRNAs exist in the genome as single copies, multiple copies or gene clusters, have fixed gene loci, and are highly conserved through evolution. In animals, miRNA seed regions, which span 2-8 nucleotides at the $5^{\prime}$ end, are critical for mRNA recognition. Considering the short seed region, individual miRNAs can target hundreds or even thousands of different mRNAs, and similarly, individual mRNAs can be coordinately suppressed by various miRNAs. However, despite seemingly non-selective binding activity of miRNAs, reports that certain genes are preferentially targeted suggest that miRNA-led inhibition may not be of random chance, but through an unknown yet sophisticated targeting mechanism. While in silico analyses provide predicted targets, the standard confirmation for miRNA-mRNA binding is through biological assay, where a luciferase reporter fused to $3^{\prime}$ UTR is reduced by miRNA overexpression or expressed when there is a point mutation in the $3^{\prime}$ UTR. Unlike animals, in most plants, miRNA is perfectly complementary to the $3^{\prime}$ UTR or even the coding region of the target mRNA, and can cleave target mRNA in the complementary region, leading to gene silencing. MiRNAs are also known to be tissuespecific. For example, in Arabidopsis thaliana, miR-157 is highly expressed in seedlings 
and miR-171 is highly expressed in flowers. Interestingly, the first miRNA, Lin-4, was discovered by Ambros and Ruvkun in Caenorhabditis elegans in 1993, but it was not until the early 2000s that miRNAs were formally classified as a distinct group of non-coding biological regulators [23-26]. Since then, the field of miRNA has taken off, spanning a wide range of study areas including molecular cancer biology, immunology, neurology, etc. Today, it is well known that normal function of miRNAs in the human body is necessary for maintenance of cellular homeostasis [27,28]. MiRNAs can influence the occurrence, development, and formation of diverse diseases by regulating cell proliferation, apoptosis, cell differentiation, cell cycle, hormone secretion, and biological development $[27,29,30]$. MiRNAs have been evidenced to participate in a multitude of cellular activities, including cell fate determination, proliferation, apoptosis, immune response circadian rhythm, viral replication, hormone secretion, etc. [24,31-35]. For example, miR-29a plays a crucial role in the dysregulation of metabolism and inflammatory signaling linked to NAFLD severity and progression [36]. The miR-15 family is capable of promoting cell cycle arrest and suppressing mitotic genes [37]. MiR-155 upregulation represents an important signal in various inflammatory diseases, some clinical trials have suggested this association as a biomarker for inflammation [38]. Downregulation of miR-146a may contribute to severe COVID-19 symptoms in patients suffering from diabetes, obesity, and hypertension [39]. MiRNAs have also been proposed to serve as early diagnostic biomarkers for identifying high-risk subjects and early cancer stages [40]. Large-scale miRNA dysregulation can be found in almost all cancer types. In particular, accumulating evidence has revealed that exosomal miRNA plays a critical role in mediating favorable microenvironment for lung cancer development. More importantly, tumor cells have been evidenced to promote an immunosuppressive and chemoresistant environment through exosomal regulation, part of which may be due to the role of miRNA in actively regulating the epigenetic landscape.

\section{Exosomes}

Exosomes are extracellular vesicles released by living cells, with a diameter ranging between 30 100 nm, and a density between 1.13-1.19 g/mL [41-43]. Exosomes were initially described by Johnstone as being uniquely secreted by reticulocytes [44,45]. The main biogenesis mechanism is through the invagination of intracellular lysosomal particles, which is released into the extracellular space after fusing with the cell membrane [46-50]. It is found that almost all cells can secrete exosomes under both normal and pathological conditions, including reticulocytes, dendritic cells, lymphocytes, platelets, mast cells, and tumor cells $[44,51]$. Exosomes can be detected in urine, cerebrospinal fluid, saliva, sputum, serum, plasma, milk, semen, pleural effusion, amniotic fluid, and other biological fluids [46,52-57]. While the composition of exosomes is similar to and determined by their parental cells, it is interesting to note that exosomes released by all cell types contain several common marker proteins, including CD63, CD81, CD9, TSG-101, and ALIX [47,58,59].

Exosomes are efficient in transmiting signals and transferring biologically active molecules such as proteins, growth factors, cytokines, RNAs, DNAs, and lipids [46,48,51,60,61]. During the transferring process, these biologically active molecules are surrounded by a lipid bilayer membrane composed of cholesterol, phosphatidylserine, and sphingolipids, and thus protected from degradataion. Active contents propageted by exosomes can serve as stable signaling molecules mediating cell-cell communication and participating in various cancer-related biological activities including cell migration, angiogenesis, pre-metastasis niche formation, drug resistance, and immune regulation [41,62-70]. The secretion and transportation of exosomes are accomplished through two main pathways. The first mechanism requires the endosomal sorting and transport complex (ESCRT). ESCRT is composed of four proteins (ESCRT-0, ESCRT-I, ESCRT-II, and ESCRT-III), and functions to package biomolecules in the internal cavity of exosomes. The other secretion method is the ESCRTindependent mechanism, which requires the help of sphingolipids [41,44,71,72]. Once released by the parent cell, exosomes can interact with neighboring or distant cells through at least three mechanisms: (i) interaction between the exosomal transmembrane protein 
and the signal receptor of the recipient cell, (ii) fusion with the plasma membrane of the recipient cell and release of their contents into the cytosol, (iii) internalization of exosomes into the recipient cell through endocytosis [73]. Studies have shown that exosomal miRNAs released in the cytoplasm are functional and may induce changes in the function and phenotype of recipient cells $[74,75]$. Existing data show that packaging of microribonucleic acid into exosomes is a selective process. When tumor cells develop, levels of specific exosomal microribonucleic acids will change. For these reasons, exosomal miRNA can also act as potential candidate biomarkers for clinical applications [76]. Accumulating evidence shows that exosomal miRNAs, especially miR-210, may play a key role in changing the microenvironment of lung cancer, and may promote progression, invasion, angiogenesis, metastasis, and drug resistance.

\section{MiR-210 Function in Cancer}

MiR-210 exists in two forms: miR-210-3p (guide strand) and miR-210-5p (passenger strand). Most studies in literature focus on miR-210-3p since it can mature into functional miRNA and integrate with the RNA-induced silencing complex (RISC), while the passenger strand is meant for degradation $[77,78]$. MiR-210 is highly involved in a variety of biological processes including mitochondrial metabolism, angiogenesis, cell proliferation, apoptosis, and erythropoiesis [79-82]. MiR-210-3p has shown both oncogenic and tumor suppressive properties. MiR-210 expression is elevated in renal cell carcinoma (RCC), hepatocellular carcinoma, breast cancer, colorectal cancer, pancreatic cancer, and lung cancer [83,84]. In RCC patients, miR-210-3p levels are found to be especially high in urine [85]. In bladder cancer, miR-210-3p has been evidenced to inhibit tumor growth by targeting fibroblast growth factor receptor-like 1 (FGFRL1) and promote prostate cancer cell epithelial-mesenchymal transition (EMT) and bone metastasis by targeting the NF-kB signaling pathway [86]. In colon cancer patients, high miR-210 levels are correlated with metastasis and poor prognosis [87]. Moreover, in colorectal and hepatocellular carcinoma cells, overexpression of miR-210 has been evidenced to inhibit vacuole membrane protein 1 (VMP1) and enhance migration and invasion [88-91].

Target prediction software such as TargetScan and PicTar have revealed various potential miR-210 targets, including E2F transcription factor 3 (E2F3), RAD52, and Max's Next Tango (MNT), and reflect the potential roles of miR-210 in regulating cell cycle, proliferation, and genome integrity [78]. MNT is a transcription factor that competes with c-MYC for max binding and is critical for cell cycle progression [92-94]. miR-210 has been evidenced to bind to the $3^{\prime} \mathrm{UTR}$ region of MNT under hypoxic conditions to inhibit its transcription and indirectly promote c-MYC activation and cell cycle progression [79]. Conversely, knockdown of miR-210 can lead to the overexpression of MNT and cell cycle arrest, as shown in glioma stem cells [95]. Furthermore, miR-210 has been demonstrated to inhibit E2F3 expression, which is known to preferentially target tumor suppressor genes and inhibit cell proliferation [96,97]. In addition to cell cycle control, miR-210 has also been implicated in disruptions of DNA damage repair pathways. For example, cells overexpressing miR-210 exhibit low levels of RAD52 and greater instances of DNA strand breaks [98]. Similar to BRCA2, RAD52 serves to recruit RAD51 to repair double-strand breaks through nucleoprotein filament formation $[89,97,99,100]$.

In vitro studies have found that miR-210-induced VEGF expression promoted cancer cell migration and angiogenesis [101]. Angiogenesis, a process of new blood vessel formation, is particularly important for cancer cell proliferation and metastasis. Hypoxia-induced miR-210 overexpression triggers lactic acid fermentation and increase in glucose transporter GLUT-1. GLUT-1 upregulation is often found coupled with vascular endothelial growth factor (VEGF) and platelet-derived growth factor (PDGF) expression, creating favorable conditions for angiogenesis [102]. Alternatively, miR-210 can also promote VEGF expression through the inhibition of phosphor-tyrosine phosphatase-1B (PTP1B) and Ephrin-A3(EFNA3) [98]. Moreover, its role in regulating hypoxia-inducible factors (HIFs) under low oxygen (hypoxic) conditions is well documented. Notably, hypoxia is a common 
feature found in many cancer types, as the demand for oxygen in proliferating tumor tissues eventually exceeds the supply. Under normal circumstances, glycerol-3-phosphate dehydrogenase 1-like (GPD1L) activates prolyl-hydroxylase domain isoforms (PHDs) to promote HIF-1 proline hydroxylation and proteasomal degradation. However, under hypoxic conditions, elevated miR-210 expression inhibits GPD1L through mRNA 3'UTR binding, and results in HIF-1 accumulation [103,104]. HIF-1 accumulation can up-regulate CA9, COX2, and VEGFA, thereby adapting to hypoxic conditions [105]. Noted, miR-210HIF-1 interaction is bi-directional. When the oxygen level decreases, increase in HIF-1 protein can also promote miR-210 accumulation, indicative of a positive feedback loop. Moreover, upon hypoxic stress, miR-210 can inhibit DNA repair factor RAD52, increase ROS production, and decrease mitochondrial respiratory activity $[77,79,106]$. Notably, hypoxia can also promote exosomal miR-210 release through increased production of tissue inhibitor of metalloproteinases-1 (TIMP-1). TIMP-1 has been evidenced to promote angiogenic tubulogenesis through upregulation of miR-210 expression via the PI3K/AKT pathway [107]. Current studies indicate that exosomes excreted by hypoxic cancer cells may be responsible for promoting tumor progression via miR-210 secretion $[108,109]$. For example, circulating exosomes isolated from breast cancer and colorectal cancer patients show increased miR-210 expression $[90,110]$.

\section{Mechanisms of Exosomal miR-210 in Lung Cancer}

In 2009, Rabinowits et al. first reported that miRNAs extracted from NSCLC tissue can serve as diagnostic biomarkers [111,112]. Since then, various miRNAs have been implicated in the development of lung cancer, and miR-21 has been one of the most extensively studied candidates. However, while dysregulation of exosomal miR-210 has been reported in human, cell, and animal studies (Table 1), less is known about its underlying mechanisms in lung cancer. This section will examine all currently known mechanistic pathways involved in exosomal miR-210-mediated lung cancer.

Table 1. MiR-210 expression in human, cell, and mouse models.

\begin{tabular}{|c|c|c|c|c|c|c|}
\hline Exosomal miRNA & $\operatorname{miR}-210$ & miR-210-3p & $\operatorname{miR}-210-3 p$ & miR-210-3p & $\operatorname{miR}-210$ & $\operatorname{miR-210}$ \\
\hline Expression Level & Up & Up & Up & Up & Up & Up \\
\hline Sample Source & Human & Cell & Cell & Cell & Cell & $\begin{array}{l}\text { Fox Chase SCID } \\
\text { mice }\end{array}$ \\
\hline Sample Type & Pleural effusion & $\begin{array}{l}\text { HCC } 827 \text { cells, } \\
\text { PC-9 cells, } \\
\text { HCC } 827-O R \text { cells, } \\
\text { PC-9-OR cells }\end{array}$ & $\begin{array}{l}\text { H358 cells, A549 } \\
\text { cells, H460 cells }\end{array}$ & $\begin{array}{l}\text { A549 cells, } \\
\text { NCIH1703 cells, } \\
\text { BEAS-2B cells }\end{array}$ & $\begin{array}{c}\text { A549 cells, } \\
\text { HEK-293/EBNA } \\
\text { cells }\end{array}$ & Plasma \\
\hline $\begin{array}{c}\text { Exosome } \\
\text { Isolation Method }\end{array}$ & $\begin{array}{c}\text { Exosome } \\
\text { isolation reagents } \\
\text { (Invitrogen) }\end{array}$ & $\begin{array}{c}\text { differential } \\
\text { centrifugation }\end{array}$ & EXO Quick & ultracentrifugation & ExoQuick-TC & ExoQuick-TC \\
\hline $\begin{array}{l}\text { miRNA Detection } \\
\text { Method }\end{array}$ & qRT-PCR & $\begin{array}{c}\text { miRNA } \\
\text { microarray and } \\
\text { qRT-PCR }\end{array}$ & $\begin{array}{l}\text { miRNA } \\
\text { microarray }\end{array}$ & qRT-PCR & qRT-PCR & qRT-PCR \\
\hline $\begin{array}{l}\text { Upstream } \\
\text { Regulator }\end{array}$ & unknown & unknown & unknown & unknown & TIMP-1 & TIMP-1 \\
\hline $\begin{array}{l}\text { Downstream } \\
\text { Target }\end{array}$ & unknown & unknown & STAT3 signalling & FGFRL1 & EphA3 & $\begin{array}{c}\text { FGFRL1, E2F3, } \\
\text { VMP-1, RAD52 } \\
\text { and SDHD }\end{array}$ \\
\hline Function & unknown & Drug resistance & $\begin{array}{c}\text { Invasion, } \\
\text { Metastasis, EMT }\end{array}$ & pro-proliferative & Angiogenesis & Vascularization \\
\hline $\begin{array}{l}\text { Cancer Type } \\
\text { Reference }\end{array}$ & $\begin{array}{c}\text { adenocarcinoma } \\
{[9]}\end{array}$ & $\begin{array}{c}\text { NSCLC } \\
\text { [113] }\end{array}$ & $\begin{array}{c}\text { NSCLC } \\
\text { [114] }\end{array}$ & $\begin{array}{c}\text { Not specified } \\
\text { [103] }\end{array}$ & $\begin{array}{c}\text { adenocarcinoma } \\
{[102]}\end{array}$ & $\begin{array}{c}\text { adenocarcinoma } \\
{[107]}\end{array}$ \\
\hline
\end{tabular}

\subsection{Signal Transducer and Activator of Transcription 3 (STAT3)}

Hypoxic bone marrow-derived mesenchymal stem cells (BMSCs) have been evidenced to transfer exosomal miRNAs to promote lung cancer metastasis. Specifically, lung cancer cells (A549, LLC, H460, and H358) treated with hypoxic BMSC-derived exosomes demonstrated increased migration and invasion potentials compared to normoxic BMSC-secreted 
exosomes [114]. Hypoxic BMSC-derived exosomes were especially rich in miR-193a-3p, miR-210-3p, and miR-5100. Furthermore, BMSC-derived exosomes promoted both the total and phosphorylated STAT3 levels [114]. STAT3 is known to be overexpressed in cancer cells, and functions to elicit production of immunosuppressive factors. Moreover, miR210-3p inhibitor was capable of reducing phosphorylated STAT3 expression. The study further analyzed plasma exosomes and found significantly upregulated miR-210-3p levels in metastatic lung cancer patients compared to non-metastatic lung cancer patients and healthy controls, suggesting that miR-210 may play an important role in lung metastasis. Specifically, miR-210-3p is capable of targeting STAT3 inhibitor, suppressor of cytokine signaling 1 (SOCS1) [115]. Interestingly, miR-210-5p has also been shown to directly target SOCS1 in RCC [116].

\subsection{Fibroblast Growth Factor Receptor Like 1 (FGFRL1)}

Cancer cells have high heterogeneity and contain a variety of cell types. Cancer stem cells (CSCs) for example, make up a small population of cancer cells, and are characterized by enhanced self-renewal and chemo/radiotherapy resistance capabilities, which make them the main mediators for sustained cancer growth. Lung CSC-derived exosomes have been evidenced to contain high levels of miR-210-3p and enhance lung cancer cell migration and invasion, through the inhibition of E-cadherin as well as the promotion of vimentin, N-cadherin, MMP-9, and MMP-1 expression, which are phenotypic hallmarks for EMT and enhanced invasive potential [103]. Moreover, the study indicated that miR-210-3p may contribute to cancer cell metastasis via the inhibition of FGFRL1. FGFRL1 is part of the FGFR family and has been reported to modulate ERK1/2 and FGF signaling pathways [117]. Recently, FGFRL1 has been associated with prostate, gastric, oesophageal, and ovarian cancer cell proliferation and metastasis $[118,119]$. In particular, miR-210 has been evidenced to promote angiogenesis by targeting FGFRL1 in hepatocellular carcinoma and osteosarcoma cells $[120,121]$. However, in oesophageal squamous cell carcinoma, laryngocarcinoma, and bladder cancer, miR-210-3p has showed tumor suppressive properties through FGFRL1 binding $[91,120,122]$. These conflicting results suggest that miR-210-3p and FGFRL1 may have dual roles in cancer.

\subsection{PI3K/AKT Pathway}

Runt-related transcription factor-3 (RUNX3) is primarily involved in cartilage mineralization and chondrocyte maturation, though evidence suggests that miRNA-regulated RUNX3 is capable of influencing phosphatidylinositol-3-kinase protein kinase B (PI3K/AKT) signaling pathway, which is crucial for cancer cell proliferation [123-125]. RUNX3 is correlated with poor prognosis and shorter survival in NSCLC patients [126,127]. A study led by Li et al. reported that miR-210 was capable of inhibiting RUNX3, thereby activating PI3K/AKT signaling pathway and promoting malignant phenotype of lung cancer cells [127]. Conversely, the inhibition of miR-210 or PI3K/AKT signaling pathway via LY294002 treatment reversed malignant potential of lung cancer cells. In addition to RUNX3, PTEN is another well-known regulator of the PI3K/AKT signaling pathway. For example, overexpression of miR-210 has been shown to promote NSCLC cell migration and invasion through UPF1 suppression followed by upregulation of the PTEN/PI3K/AKT pathway [128]. More recently, miR-210 upregulation has been reported to inhibit upstream stimulating factor 1 (USF-1) and polycomb group ring (PCGF3) [129]. USF-1 is a transcription factor belonging to the basic helix-loop-helix leucine zipper family, and is known to regulate hepatocellular carcinoma, papillary thyroid as well as lung cancer [130]. Interestingly, PCGF3 has also been reported to promote cell proliferation in NSCLC via the PI3K/AKT signaling pathway [131]. Moreover, miR-210-mediated PI3K/AKT signaling has also been reported in oral cancer. Notably, in oral squamous cell carcinoma, elevated exosomal miR-210-3p levels can inhibit ephrinA3 expression and in turn activate PI3K/AKT signaling pathway [132]. Overall, these studies suggest that miR-210 can alter PI3K/AKT through various factors, and that this phenomenon is not limited to lung cancer. 


\subsection{Tissue Inhibitor of Metalloproteinases-1 (TIMP-1)}

TIMP-1 is known to regulate protease homeostasis via the inhibition of metzincin [133,134]. Its ability to inhibit matrix metalloproteinases (MMPs) and A-disintegrin-and-metalloproteinase (ADAM-10) reflect anti-tumorigenic characteristics. However, increased TIMP-1 expression is often correlated with poor prognosis, especially in ovarian, lung, gastric, and papillary thyroid carcinoma [135-140]. Interestingly, TIMP-1 serves as a positive regulator of PI3Ks and has been evidenced to promote cancer cell growth via AKT/ERK phosphorylation [141-145]. A study led by Cui et al. showed that an increase in TIMP-1 promoted lung cancer progression through activating the PI3K/AKT/HIF-1 signaling pathway and miR-210 expression [107]. Specifically, high levels of miR-210 were found in exosomes derived from TIMP-1 overexpressing A549L cells, and that its expression level was dependent on HIF-1 accumulation. Conversely, a reduction in miR-210 can effectively inhibit A549L cell growth, suggesting its important role in cancer cell proliferation. Previous research has reported that hypoxia promotes exosome secretion of miR-210, suggesting a mechanism of a self-sustaining hypoxia state. Moreover, the study finds that levels of mature miR-210 was dependent on CD63, an interacting partner of TIMP-1, providing novel insight into the mechanism of elevated miR-210 in lung cancer.

\subsection{Epidermal Growth Factor Receptor (EGFR)-Mutant Drug Resistance}

Osimertinib is a tyrosine kinase inhibitor, specifically designed to treat EGFR-mutant non-small cell lung cancer $[146,147]$. Despite its effectiveness compared to previous two generations of EGFR-tyrosine kinase inhibitors (EGFR-TKIs), multiple studies have reported resistance to osimertinib, due to varying mechanisms, including EGFR mutation, KRAS mutation, BRAF mutation, loss of T900M mutation, or HER2 amplification [148]. Using microarray and qRT-PCR, Hisakane et al. reported high levels of exosomal miR210 in osimertinib-resistant HCC827-OR and PC-9-OR cells compared to HCC827 and PC-9 parental cells [113]. Moreover, co-culturing exosomes isolated from osimertinibresistant cells as well as induction of miR-210 both led to drug resistance and EMT in oximertinib-sensitive cells. However, there was no evidence that miR-210 acted via the EGFR signaling pathway, suggesting the involvement of a bypass mechanism. The study points to E-cadherin as a potential mediating factor associated with EMT. In addition, exosomes isolated from colorectal cancer cells and pancreatic cancer stem cells have also been found to carry high abundance of miR-210 and are correlated with fluorouacil and gemcitabine resistance [149-151].

\subsection{KRAS BACH2/GATA-3/RIP-3}

Mutant KRAS is a well-known driver of lung neoplasia, part of which functions through secreting exosomes to manipulate tumor microenvironment favorable for hypoxic immunosuppression [152-154]. Interestingly, in KRAS chemoresistant lung cancer tissues from human patients, high abundance of miR-146 and miR-210 were found compared to non-KRAS metastatic samples [154]. Moreover, post KRAS exosome inhibition, miR210 expression levels were reduced, suggesting a direct relationship between KRAS and miR-210 levels. In addition, levels of miR-146/miR-210 were found at lower levels in lymph node metastatic tissues, indicating their importance in primary lung tumor. The study went on to report that KRAS was capable of regulating chromatin remodeling genes SMARCE1/NCOR1, which play key roles in chemosresistant metastasis, as well as transcription factor BACH2/GATA-3 expression through pyruvate/PKM2-dependent metabolism, thereby contributing to sustained immunosuppressive metastasis [154]. Although the mechanism of how miR-210 is regulated by KRAS remains elusive, there is clear evidence that PKM2 is an HIF-1 target gene [155].

\section{Conclusions}

Studies on exosomal miRNA represent a growing niche for cancer biology. While human and animal model studies use similar methods including miRNA-seq, qRT-PCR 
for the purpose of finding potential diagnostic biomarkers, there are only a few consistent results among currently available studies. The vast number of dysregulated miRNAs reported makes it difficult to pinpoint which miRNA is responsible for the development of lung cancer. Currently, there is a limited amount of research on the role of exosomal $\mathrm{miR}-210$ in lung cancer, but dysregulation of its expression has been reported in various human, cell, and animal models. The consistency in its dysregulated expression found under various contexts suggests that miR-210 may play an important role in lung cancer development. MiR-210 is a well-known hypoxia-related miRNA and has been evidenced to mediate both oncogenic and tumor suppressive properties. Confirmed miR-210 downstream targets include STAT3 and FGFRL1; however, less is known about its upstream targets. Future studies may benefit from investigating probable miR-210 regulators as well as potential exosomal inhibitors and anti-miR-210 agents for therapeutic purposes.

Author Contributions: Q.C. conceived the presented review. X.X. and Q.C. wrote and edited the manuscript. Both authors have read and agreed to the submitted version of the manuscript.

Funding: This research received no external funding.

Institutional Review Board Statement: Not applicable.

Informed Consent Statement: Not applicable.

Data Availability Statement: Not applicable.

Conflicts of Interest: The authors declare no conflict of interest.

\section{References}

1. Fan, T.; Sun, N.; He, J. Exosome-Derived LncRNAs in Lung Cancer. Front. Oncol. 2020, 10, 1728. [CrossRef]

2. Alipoor, S.D.; Mortaz, E.; Varahram, M.; Movassaghi, M.; Kraneveld, A.D.; Garssen, J.; Adcock, I.M. The Potential Biomarkers and Immunological Effects of Tumor-Derived Exosomes in Lung Cancer. Front. Immunol. 2018, 9, 819. [CrossRef]

3. Masaoutis, C.; Mihailidou, C.; Tsourouflis, G.; Theocharis, S. Exosomes in lung cancer diagnosis and treatment. From the translating research into future clinical practice. Biochimie 2018, 151, 27-36. [CrossRef]

4. Iqbal, M.A.; Arora, S.; Prakasam, G.; Calin, G.A.; Syed, M.A. MicroRNA in lung cancer: Role, mechanisms, pathways and therapeutic relevance. Mol. Aspects Med. 2019, 70, 3-20. [CrossRef]

5. de Miguel Pérez, D.; Martínez, A.R.; Palomo, A.O.; Ureña, M.D.; Puche, J.L.G.; Remacho, A.R.; Hernandez, J.E.; Acosta, J.A.L.; Sánchez, F.G.O.; Serrano, M.J. Extracellular vesicle-miRNAs as liquid biopsy biomarkers for disease identification and prognosis in metastatic colorectal cancer patients. Sci. Rep. 2020, 10, 1-13. [CrossRef]

6. Ferracin, M.; Lupini, L.; Salamon, I.; Saccenti, E.; Zanzi, M.V.; Rocchi, A.; Da, R.L.; Zagatti, B.; Musa, G.; Bassi, C.; et al. Absolute quantification of cell-free microRNAs in cancer patients. Oncotarget 2015, 6, 14545-14555. [CrossRef] [PubMed]

7. Turchinovich, A.; Tonevitsky, A.G.; Burwinkel, B. Extracellular miRNA: A Collision of Two Paradigms. Trends Biochem. Sci. 2016, 41, 883-892. [CrossRef]

8. Guan, P.; Yin, Z.; Li, X.; Wu, W.; Zhou, B. Meta-analysis of human lung cancer microRNA expression profiling studies comparing cancer tissues with normal tissues. J. Exp. Clin. Cancer Res. 2012, 31, 54. [CrossRef]

9. Tamiya, H.; Mitani, A.; Saito, A.; Ishimori, T.; Saito, M.; Isago, H.; Jo, T.; Yamauchi, Y.; Tanaka, G.; Nagase, T. Exosomal MicroRNA Expression Profiling in Patients with Lung Adenocarcinoma-associated Malignant Pleural Effusion. Anticancer Res. 2018, 38, 6707-6714. [CrossRef] [PubMed]

10. Ulivi, P.; Zoli, W. miRNAs as Non-Invasive Biomarkers for Lung Cancer Diagnosis. Molecules 2014, 19, 8220-8237. [CrossRef] [PubMed]

11. Võsa, U.; Vooder, T.; Kolde, R.; Vilo, J.; Metspalu, A.; Annilo, T. Meta-analysis of microRNA expression in lung cancer. Int. J. Cancer 2013, 132, 2884-2893. [CrossRef]

12. Tian, F.; Tang, P.; Sun, Z.L.; Zhang, R.F.; Zhu, D.H.; He, J.Y.; Liao, J.X.; Wan, Q.H.; Shen, J. miR-210 in exosomes derived from macrophages under high glucose promotes mouse diabetic obesity pathogenesis by suppressing NDUFA4 expression. J. Diabetes Res. 2020, 2020, 689486. [CrossRef]

13. Wang, L.R.; Jia, Q.J.; Chen, X.N.; Xie, Y.Y.; Yang, Y.Q.; Zhang, A.; Liu, R.T.; Zhuo, Y.; Zhang, J.P. Role of cardiac progenitor cell-derived exosome-mediated microRNA-210 in cardiovascular disease. J. Cell. Mol. Med. 2019, 23, 7124-7131. [CrossRef]

14. Biró, O.; Fóthi, Á.; Alasztics, B.; Nagy, B.; Orbán, T.I.; Rigó, J. Circulating exosomal and Argonaute-bound microRNAs in preeclampsia. Gene 2019, 692, 138-144. [CrossRef]

15. Ha, M.; Kim, V.N. Regulation of microRNA biogenesis. Nat. Rev. 2014, 15, 509-524. [CrossRef] [PubMed]

16. O'Brien, J.; Hayder, H.; Zayed, Y.; Peng, C. Overview of MicroRNA Biogenesis, Mechanisms of Actions, and Circulation. Front. Endocrinol 2018, 9, 402. [CrossRef] [PubMed] 
17. de Rie, D.; Abugessaisa, I.; Alam, T.; Arner, E.; Arner, P.; Ashoor, H.; Åström, G.; Babina, M.; Bertin, N.; Burroughs, A.M.; et al. An integrated expression atlas of miRNAs and their promoters in human and mouse. Nat. Bioltechnol. 2017, 35, 872-878. [CrossRef]

18. Gebert, L.; Macrae, I.J. Regulation of microRNA function in animals. Nat. Rev. Mol. Cell Biol. 2018, 20, 21-37. [CrossRef]

19. Trabucchi, M.; Mategot, R. Subcellular Heterogeneity of the microRNA Machinery. Trends Genet. 2018, 35, 15-28. [CrossRef] [PubMed]

20. Denli, A.M.; Tops, B.B.J.; Plasterk, R.H.A.; Ketting, R.F.; Hannon, G.J. Processing of primary microRNAs by the Microprocessor complex. Nature 2004, 432, 231-235. [CrossRef] [PubMed]

21. Han, J.; Lee, Y.; Yeom, K.; Kim, Y.; Jin, H.; Kim, V.N. The Drosha-DGCR8 complex in primary microRNA processing. Gene Dev. 2004, 18, 3016-3027. [CrossRef] [PubMed]

22. Zhang, H.; Kolb, F.A.; Jaskiewicz, L.; Westhof, E.; Filipowicz, W. Single processing center models for human Dicer and bacterial RNase III. Cell 2004, 118, 57-68. [CrossRef]

23. Lee, R.C.; Feinbaum, R.L.; Ambros, V. The C. elegans heterochronic gene lin-4 encodes small RNAs with antisense complementarity to lin-14. Cell 1993, 75, 843-854. [CrossRef]

24. Lee, Y.S.; Anindya, D. MicroRNAs in Cancer. Ann. Rev. Pathol. 2009, 4, 199-227. [CrossRef] [PubMed]

25. Lin, S.B.; Gregory, R.I. MicroRNA biogenesis pathways in cancer. Nat. Rev. Cancer 2015, 15, 321-333. [CrossRef]

26. Wightman, B.; Ha, I.; Ruvkun, G. Posttranscriptional regulation of the heterochronic gene lin-14 by lin-4 mediates temporal pattern formation in C. elegans. Cell 1993, 75, 855-862. [CrossRef]

27. Doench, J.G.; Peterson, C.P.; Sharp, P.A. The functions of animal microRNAs. Nature 2004, 431, 350-355.

28. Mckale, D.; Stephen, C. Influence of microRNA on the Maintenance of Human Iron Metabolism. Nutrients 2013, 5, $2611-2628$.

29. Krol, J.; Loedige, I.; Filipowicz, W. The widespread regulation of microRNA biogenesis, function and decay. Nat. Rev. Genet. 2010, 11, 597-610. [CrossRef]

30. Saliminejad, K.; Khorshid, H.; Fard, S.S.; Ghaffari, S.H. An overview of microRNAs: Biology, functions, therapeutics, and analysis methods. J. Cell Phisol. 2019, 234, 5451-5465. [CrossRef]

31. Chen, Q.Y.; Des Marais, T.; Costa, M. Deregulation of SATB2 in carcinogenesis with emphasis on miRNA-mediated control. Carcinogenesis 2019, 40, 393-402. [CrossRef]

32. Cheng, H.M.; Papp, J.W.; Varlamova, O.; Dziema, H.; Russell, B.; Curfman, J.P.; Nakazawa, T.; Shimizu, K.; Okamura, H.; Impey, S.; et al. microRNA Modulation of Circadian-Clock Period and Entrainment. Neuron 2007, 54, 813-829. [CrossRef]

33. Gantier, M.P.; Sadler, A.J.; Williams, B.R.G. Fine-tuning of the innate immune response by microRNAs. Immunol. Cell Biol. 2007, 85, 458-462. [CrossRef]

34. Jopling, C.L. Modulation of Hepatitis C Virus RNA Abundance by a Liver-Specific MicroRNA. Science 2005, 309, 1577-1581. [CrossRef]

35. Poy, M.N.; Lena, E.; Jan, K.; Satoru, K.; Ma, X.S.; MacDonald, P.E.; Pfeffer, S.B.; Thomas, T.; Nikolaus, R.; Patrik, R.; et al. A pancreatic islet-specific microRNA regulates insulin secretion. Nature 2004, 432, 226-230. [CrossRef]

36. Lin, H.; Yang, Y.; Wang, P.; Wang, F.; Huang, Y. The Emerging Role of MicroRNAs in NAFLD: Highlight of MicroRNA-29a in Modulating Oxidative Stress, Inflammation, and Beyond. Cells 2020, 9, 1041. [CrossRef] [PubMed]

37. Kalayiniaa, S.; Fateme, A.; Majid, M.; Mahshid, M.; Pal, S.C. MicroRNAs: Roles in cardiovascular development and disease. Cardiovasc. Pathol. 2021, 50, 107296. [CrossRef]

38. Pasca, S.; Ancuta, J.; Bobe, P.; Ciprian, T.; Daniela, M. MicroRNA-155 Implication in M1 Polarization and the Impact in Inflammatory Diseases. Front. Immunol. 2020, 11, 625. [CrossRef] [PubMed]

39. Jelena, R.C. Downregulation of microRNA-146a in diabetes, obesity and hypertension may contribute to severe COVID-19. Med. Hypotheses 2021, 146, 110448.

40. Bersimbaev, R.; Alessandra, P.; Bulgakova, O.; Assiya, K.; Aripova, A.; Izzotti, A. Radon Biomonitoring and microRNA in Lung Cancer. Int. J. Mol. Sci. 2020, 21, 2154. [CrossRef] [PubMed]

41. Smolarz, M.; Widlak, P. Serum Exosomes and Their miRNA Load-A Potential Biomarker of Lung Cancer. Cancers 2021, $13,1373$. [CrossRef] [PubMed]

42. Taverna, S.; Giallombardo, M.; Gil-Bazo, I.; Carreca, A.P.; Castiglia, M.; Chacártegui, J.; Araujo, A.; Alessandro, R.; Pauwels, P.; Peeters, M.; et al. Exosomes isolation and characterization in serum is feasible in non-small cell lung cancer patients: Critical analysis of evidence and potential role in clinical practice. Oncotarget 2016, 7, 28748-28760. [CrossRef] [PubMed]

43. Zduriencikova, M.; Gronesova, P.; Cholujova, D.; Sedlak, J. Potential biomarkers of exosomal cargo in endocrine signaling. Endocr. Regul. 2015, 49, 141-150. [CrossRef]

44. Frydrychowicz, M.; Kolecka-Bednarczyk, A.; Madejczyk, M.; Yasar, S.; Dworacki, G. Exosome-Structure, Biogenesis and Biological Role in Non-Small-Cell Lung Cancer. Scand. J. Immunol. 2015, 81, 2-10. [CrossRef] [PubMed]

45. Johnstone, R.M.; Adam, M.; Hammond, J.R.; Orr, L.; Turbide, C. Vesicle formation during reticulocyte maturation. Association of plasma membrane activities with released vesicles (exosomes). J. Biol. Chem. 1987, 262, 9412-9420. [CrossRef]

46. Freitas, C.; Sousa, C.; Machado, F.; Serino, M.; Santos, V.; Cruz-Martins, N.; Teixeira, A.; Cunha, A.; Pereira, T.; Oliveira, H.P.; et al. The Role of Liquid Biopsy in Early Diagnosis of Lung Cancer. Front. Oncol. 2021, 11, 634316. [CrossRef]

47. Mahgoub, E.O.; Razmara, E.; Bitaraf, A.; Norouzi, F.; Montazeri, M.; Behzadi-Andouhjerdi, R.; Falahati, M.; Cheng, K.; Haik, Y.; Hasan, A.; et al. Advances of exosome isolation techniques in lung cancer. Mol. Biol. Rep. 2020, 47, 7229-7251. [CrossRef] 
48. Mathivanan, S.; Ji, H.; Simpson, R.J. Exosomes: Extracellular organelles important in intercellular communication. J. Proteom. 2010, 73, 1907-1920. [CrossRef]

49. Raposo, G.; Stoorvogel, W. Extracellular vesicles: Exosomes, microvesicles, and friends. J. Cell Biol. 2013, 200, 373-383. [CrossRef]

50. Reclusa, P.; Taverna, S.; Pucci, M.; Durendez, E.; Calabuig, S.; Manca, P.; Serrano, M.J.; Sober, L.; Pauwels, P.; Russo, A.; et al. Exosomes as diagnostic and predictive biomarkers in lung cancer. J. Thorac. Dis. 2017, 9, S1373-S1382. [CrossRef]

51. Baig, M.S.; Roy, A.; Rajpoot, S.; Liu, D.; Savai, R.; Banerjee, S.; Kawada, M.; Faisal, S.M.; Saluja, R.; Saqib, U.; et al. Tumor-derived exosomes in the regulation of macrophage polarization. Inflamm. Res. 2020, 69, 435-451. [CrossRef] [PubMed]

52. Andre, F.; Schartz, N.E.; Movassagh, M.; Flament, C.; Pautier, P.; Morice, P.; Pomel, C.; Lhomme, C.; Escudier, B.; Le Chevalier, T.; et al. Malignant effusions and immunogenic tumour-derived exosomes. Lancet. 2002, 360, 295-305. [CrossRef]

53. Cui, S.; Cheng, Z.; Qin, W.; Jiang, L. Exosomes as a liquid biopsy for lung cancer. Lung Cancer 2018, 116, 46-54. [CrossRef] [PubMed]

54. Guiot, J.; Struman, I.; Louis, E.; Louis, R.; Malaise, M.; Njock, M. Exosomal miRNAs in Lung Diseases: From Biologic Function to Therapeutic Targets. J. Clin. Med. 2019, 8, 1345. [CrossRef] [PubMed]

55. Harischandra, D.S.; Ghaisas, S.; Rokad, D.; Kanthasamy, A.G. Exosomes in Toxicology: Relevance to Chemical Exposure and Pathogenesis of Environmentally Linked Diseases. Toxicol. Sci. 2017, 158, 3-13. [CrossRef] [PubMed]

56. Reclusa, P.; Sirera, R.; Araujo, A.; Giallombardo, M.; Valentino, A.; Sorber, L.; Bazo, I.G.; Pauwels, P.; Rolfo, C. Exosomes genetic cargo in lung cancer: A truly Pandora's box. Transl. Lung Cancer Res. 2016, 5, 483-491. [CrossRef]

57. Song, Z.P.; Liu, Y. Progress of Liquid Biopsy in Early Diagnosis of Lung Cancer. Chin. J. Lung Cancer 2018, $21,620-627$.

58. Joanna, K.; Mercedes, T.; Clotilde, T. Biogenesis and secretion of exosomes. Curr. Opin. Cell Biol. 2014, 29, 116-125.

59. Yanez-Mo, M.; Siljander, P.R.; Andreu, Z.; Zavec, A.B.; Borras, F.E.; Buzas, E.I.; Buzas, K.; Casal, E.; Cappello, F.; Carvalho, J.; et al. Biological properties of extracellular vesicles and their physiological functions. J. Extracell. Vesicles 2015, 4, 27066. [CrossRef]

60. Long, L.; Zhang, X.; Bai, J.; Li, Y.; Wang, X.; Zhou, Y. Tissue-specific and exosomal miRNAs in lung cancer radiotherapy: From regulatory mechanisms to clinical implications. Cancer Manag. Res. 2019, 11, 4413-4424. [CrossRef]

61. Zhang, X.; Yuan, X.; Shi, H.; Wu, L.; Qian, H.; Xu, W. Exosomes in cancer: Small particle, big player. J. Hematol. Oncol. 2015, 8, 83. [CrossRef]

62. Akoto, T.; Saini, S. Role of Exosomes in Prostate Cancer Metastasis. Int. J. Mol. Sci. 2021, 22, 3528. [CrossRef]

63. Li, Z.; Lv, T.F.; Zhang, Q.; Zhu, Q.Q.; Zhan, P.; Zhu, S.H.; Zhang, J.Y.; Song, Y. The biology, function and clinical implications of exosomes in lung cancer. Cancer Lett. 2017, 407, 84-92.

64. Li, L.; Sun, Y.; Feng, M.; Wang, L.; Liu, J. Clinical significance of blood-based miRNAs as biomarkers of non-small cell lung cancer. Oncol. Lett. 2018, 15, 8915-8925. [CrossRef] [PubMed]

65. Pan, J.; Ding, M.; Xu, K.; Yang, C.; Mao, L.J. Exosomes in diagnosis and therapy of prostate cancer. Oncotarget 2017, 8, 97693-97700. [CrossRef]

66. Skog, J.; Würdinger, T.; van Rijn, S.; Meijer, D.H.; Gainche, L.; Curry, W.T.; Carter, B.S.; Krichevsky, A.M.; Breakefield, X.O. Glioblastoma microvesicles transport RNA and proteins that promote tumour growth and provide diagnostic biomarkers. Nat. Cell Biol. 2008, 10, 1470-1476. [CrossRef]

67. Valadi, H.; Ekström, K.; Bossios, A.; Sjöstrand, M.; Lee, J.J.; Lötvall, J.O. Exosome-mediated transfer of mRNAs and microRNAs is a novel mechanism of genetic exchange between cells. Nat. Cell Biol. 2007, 9, 654-659. [CrossRef] [PubMed]

68. Vanni, I.; Alama, A.; Grossi, F.; Dal Bello, M.G.; Coco, S. Exosomes: A new horizon in lung cancer. Drug Discov. Today 2017, 22, 927-936. [CrossRef] [PubMed]

69. Whiteside, T.L. Tumor-Derived Exosomes and Their Role in Cancer Progression. Adv. Clin. Chem. 2016, 12, 103-134.

70. Whiteside, T.L. The effect of tumor-derived exosomes on immune regulation and cancer immunotherapy. Future Oncol. 2017, 13, 2583-2592. [CrossRef]

71. Fujita, Y.; Kadota, T.; Araya, J.; Ochiya, T.; Kuwano, K. Clinical Application of Mesenchymal Stem Cell-Derived Extracellular Vesicle-Based Therapeutics for Inflammatory Lung Diseases. J. Clin. Med. 2018, 7, 355. [CrossRef]

72. Srivastava, A.; Amreddy, N.; Razaq, M.; Towner, R.; Zhao, Y.D.; Ahmed, R.A.; Munshi, A.; Ramesh, R. Exosomes as Theranostics for Lung Cancer. Adv. Cancer Res. 2018, 139, 1-33.

73. Mohan, A.; Agarwal, S.; Clauss, M.; Britt, N.S.; Dhillon, N.K. Extracellular vesicles: Novel communicators in lung diseases. Respir. Res. 2020, 21, 175. [CrossRef]

74. Kara-Terki, L.; Treps, L.; Blanquart, C.; Fradin, D. Critical Roles of Tumor Extracellular Vesicles in the Microenvironment of Thoracic Cancers. Int. J. Mol. Sci. 2020, 21, 6024. [CrossRef] [PubMed]

75. Pegtel, D.M.; Cosmopoulos, K.; Thorley-Lawson, D.A.; van Eijndhoven, M.A.J.; Hopmans, E.S.; Lindenberg, J.L.; de Gruijl, T.D.; Wurdinger, T.; Middeldorp, J.M. Functional delivery of viral miRNAs via exosomes. Proc. Natl. Acad. Sci. USA 2010, 107, 6328-6333. [CrossRef] [PubMed]

76. Li, L.; Liu, H.; Liu, X.; Hu, H.; Liu, S. Clinical significance of exosomal miRNAs and proteins in three human cancers with high mortality in China. Oncol. Lett. 2019, 17, 11-22. [CrossRef]

77. Bavelloni, A.; Ramazzotti, G.; Poli, A.; Piazzi, M.; Focaccia, E.; Blalock, W.; Faenza, I. MiRNA-210: A Current Overview. Anticancer Res. 2017, 37, 6511.

78. Dang, K.; Myers, K.A. The Role of Hypoxia-Induced miR-210 in Cancer Progression. Int. J. Mol. Sci. 2015, 16, 6353-6372. [CrossRef] [PubMed] 
79. Chen, Z.; Li, Y.; Zhang, H.; Huang, P.; Luthra, R. Hypoxia-regulated microRNA-210 modulates mitochondrial function and decreases ISCU and COX10 expression. Oncogene 2010, 29, 4362. [CrossRef] [PubMed]

80. Fasanaro, P.; D'Alessandra, Y.; Di, S.V.; Melchionna, R.; Romani, S.; Pompilio, G.; Capogrossi, M. MicroRNA-210 Modulates Endothelial Cell Response to Hypoxia and Inhibits the Receptor Tyrosine Kinase Ligand Ephrin-A3. J. Biol. Chem. 2008, 283, 15878-15883. [CrossRef] [PubMed]

81. Kosaka, N.; Sugiura, K.; Yamamoto, Y.; Yoshioka, Y.; Miyazaki, H.; Komatsu, N.; Ochiya, T.; Kato, T. Identification of erythropoietin-induced microRNAs in haematopoietic cells during erythroid differentiation. Br. J. Haematol. 2010, 142, 293-300. [CrossRef] [PubMed]

82. Li, T.; Song, X.; Zhang, J.; Lei, Z.; Shi, Y.; Li, Z.; Jia, L.; Ning, L.; Yan, Y.; Xiao, Y. Protection of Human Umbilical Vein Endothelial Cells against Oxidative Stress by MicroRNA-210. Oxidative Med. Cell. Longev. 2017, 2017, 3565613. [CrossRef] [PubMed]

83. Mathew, L.K.; Simon, M.C. mir-210: A sensor for hypoxic stress during tumorigenesis. Mol. Cell 2009, 35, 737-738. [CrossRef] [PubMed]

84. Xin, H.; Ding, L.; Bennewith, K.L.; Tong, R.T.; Giaccia, A.J. Hypoxia-Inducible mir-210 Regulates Normoxic Gene Expression Involved in Tumor Initiation. Mol. Cell 2009, 35, 856-867.

85. Petrozza, V.; Pastore, A.L.; Palleschi, G.; Tito, C.; Fazi, F. Secreted miR-210-3p as non-invasive biomarker in clear cell renal cell carcinoma. Oncotarget 2017, 8, 69551-69558. [CrossRef]

86. Yang, Y.; Liu, Q.; Lu, J.; Adah, D.; Yu, S.; Zhao, S.; Yao, Y.; Qin, L.; Qin, L.; Chen, X. Exosomes from Plasmodium-infected hosts inhibit tumor angiogenesis in a murine Lewis lung cancer model. Oncogenesis 2017, 6, e351. [CrossRef]

87. Chen, J.; Wang, W.; Zhang, Y.; Chen, Y.; Hu, T. Predicting distant metastasis and chemoresistance using plasma miRNAs. Med. Oncol. 2013, 31, 799. [CrossRef]

88. Ellermeier, C.; Vang, S.; Cleveland, K.; Durand, W.; Resnick, M.B.; Brodsky, A.S. Prognostic microRNA expression signature from examination of colorectal primary and metastatic tumors. Anticancer Res. 2014, 34, 3957-3967.

89. Qin, Q.; Wei, F.; Li, B. Multiple functions of hypoxia-regulated miR-210 in cancer. J. Exp. Clin. Cancer Res. 2014, 33, 50. [CrossRef]

90. Qu, A.; Du, L.; Yang, Y.; Liu, H.; Li, J.; Wang, L.; Liu, Y.; Dong, Z.; Zhang, X.; Jiang, X. Hypoxia-Inducible MiR-210 Is an Independent Prognostic Factor and Contributes to Metastasis in Colorectal Cancer. PLoS ONE 2014, 9, e90952. [CrossRef] [PubMed]

91. Ying, Q.; Liang, L.; Guo, W.; Zha, R.; Tian, Q.; Huang, S.; Yao, J.; Ding, J.; Bao, M.; Ge, C. Hypoxia-inducible MicroRNA-210 augments the metastatic potential of tumor cells by targeting vacuole membrane protein 1 in hepatocellular carcinoma. Hepatology 2011, 54, 2064-2075. [CrossRef]

92. Link, J.M.; Hurlin, P.J. MYC needs MNT. Cell Cycle 2013, 12, 385-386. [CrossRef]

93. Nakamura, I.; Roberts, L.R. Myc, Max, and Mnt: Molecular Mechanisms of Enhancement of Cholangiocarcinogenesis by Cholestasis. Gastroenterology 2011, 141, 32-34. [CrossRef] [PubMed]

94. Zhang, Z.; Sun, H.; Dai, H.; Walsh, R.; Imakura, M.; Schelter, J.; Burchard, J.; Dai, X.; Chang, A.N.; Diaz, R.L. Imakura MicroRNA miR-210 modulates cellular response to hypoxia through the MYC antagonist MNT. Cell Cycle. 2014, 8, 2756-2768. [CrossRef]

95. Yang, W.; Wei, J.; Guo, T.; Shen, Y.; Liu, F. Knockdown of miR-210 decreases hypoxic glioma stem cells stemness and radioresistance. Exp. Cell Res. 2014, 326, 22-35. [CrossRef]

96. Vidal, M.; Valentine, M.; Harlow, E.D. The retinoblastoma protein binds to a family of E2F transcription factors. Mol. Cell. Biol. 1993, 13, 7813-7825.

97. Wang, J.; Zhao, J.; Shi, M.; Ding, Y.; Sun, H.; Yuan, F.; Zou, Z.; Lebedeva, I.V. Elevated Expression of miR-210 Predicts Poor Survival of Cancer Patients: A Systematic Review and Meta-Analysis. PLoS ONE 2014, 9, e89223. [CrossRef] [PubMed]

98. Gee, H.E.; Ivan, C.; Calin, G.A.; Ivan, M. HypoxamiRs and Cancer: From Biology to Targeted Therapy. Antioxid. Redox Signal. 2014, 21, 1220-1238. [CrossRef]

99. Chan, S.Y.; Loscalzo, J. MicroRNA-210: A unique and pleiotropic hypoxamir. Cell Cycle 2010, 9, 1072-1083. [CrossRef]

100. Feng, Z.; Scott, S.P.; Bussen, W.; Sharma, G.G.; Guo, G.; Pandita, T.K.; Powell, S.N. Rad52 inactivation is synthetically lethal with BRCA2 deficiency. Proc. Natl. Acad. Sci. USA 2011, 108, 686-691. [CrossRef]

101. Duysinx, B.C.; Corhay, J.L.; Hubin, L.; Nguyen, D.; Henket, M.; Louis, R. Diagnostic value of interleukine-6, transforming growth factor- $\beta 1$ and vascular endothelial growth factor in malignant pleural effusions. Respir. Med. 2008, 102, 1708-1714. [CrossRef]

102. Cui, H.; Sebastien, G.; Florian, S.; Bernard, M.; Achim, K. On the Pro-Metastatic Stress Response to Cancer Therapies: Evidence for a Positive Co-Operation between TIMP-1, HIF-1 $\alpha$, and miR-210. Front. Pharmacol. 2012, 3, 134. [CrossRef] [PubMed]

103. Wang, L.; He, J.; Hu, H.; Tu, L.; Sun, Z.; Liu, Y.; Luo, F. Lung CSC-derived exosomal miR-210-3p contributes to a pro-metastatic phenotype in lung cancer by targeting FGFRL1. J. Cell. Mol. Med. 2020, 24, 6324-6339. [CrossRef] [PubMed]

104. Yang, Y.; Zhang, J.; Xia, T.; Li, G.; Tian, T.; Wang, M.; Wang, R.; Zhao, L.; Yang, Y.; Lan, K. MicroRNA-210 promotes cancer angiogenesis by targeting fibroblast growth factor receptor-like1 in hepatocellular carcinoma. Oncol. Rep. 2016, 36, $2553-2562$. [CrossRef]

105. Semenza, G.L. Targeting HIF-1 for cancer therapy. Nat. Rev. Cancer 2003, 3, 721-732. [CrossRef]

106. Crosby, M.E.; Kulshreshtha, R.; Ivan, M.; Glazer, P.M. MicroRNA regulation of DNA repair gene expression in hypoxic stress. Cancer Res. 2009, 69, 1221-1229. [CrossRef] 
107. Cui, H.; Seubert, B.; Stahl, E.; Dietz, H.; Reuning, U.; Moreno-Leon, L.; Ilie, M.; Hofman, P.; Nagase, H.; Mari, B.; et al. Tissue inhibitor of metalloproteinases-1 induces a pro-tumourigenic increase of miR-210 in lung adenocarcinoma cells and their exosomes. Oncogene 2015, 34, 3640-3650. [CrossRef] [PubMed]

108. Zhang, J.; Li, S.; Li, L.; Li, M.; Guo, C.; Yao, J.; Mi, S. Exosome and Exosomal MicroRNA: Trafficking, Sorting, and Function. Genom. Proteom. Bioinform. 2015, 13, 17-24. [CrossRef]

109. King, H.W.; Michael, M.Z.; Gleadle, J.M. Hypoxic enhancement of exosome release by breast cancer cells. BMC Cancer 2012, 12, 421. [CrossRef]

110. Wang, Y.; Xu, Y.M.; Zou, Y.Q.; Lin, J.; Huang, B.; Liu, J.; Li, J.; Zhang, J.; Yang, W.M.; Min, Q.H. Identification of differential expressed PE exosomal miRNA in lung adenocarcinoma, tuberculosis, and other benign lesions. Medicine 2017, 96 , e8361. [CrossRef]

111. Hu, C.; Meiners, S.; Lukas, C.; Stathopoulos, G.T.; Chen, J. Role of exosomal microRNAs in lung cancer biology and clinical applications. Cell Prolif. 2020, 53, e12828. [CrossRef]

112. Rabinowits, G.; Gerel-Taylor, C.; Day, J.M.; Taylor, D.D.; Kloecker, G.H. Exosomal MicroRNA: A Diagnostic Marker for Lung Cancer. Clin. Lung Cancer 2009, 10, 42-46. [CrossRef] [PubMed]

113. Hisakane, K.; Seike, M.; Sugano, T.; Yoshikawa, A.; Matsuda, K.; Takano, N.; Takahashi, S.; Noro, R.; Gemma, A. Exosome-derived miR-210 involved in resistance to osimertinib and epithelial-mesenchymal transition in EGFR mutant non-small cell lung cancer cells. Thorac. Cancer 2021, 12, 1690-1698. [CrossRef]

114. Zhang, X.; Sai, B.; Wang, F.; Wang, L.; Wang, Y.; Zheng, L.; Li, G.; Tang, J.; Xiang, J. Hypoxic BMSC-derived exosomal miRNAs promote metastasis of lung cancer cells via STAT3-induced EMT. Mol. Cancer 2019, 18, 40. [CrossRef] [PubMed]

115. Ren, D.; Yang, Q.; Dai, Y.; Guo, W.; Du, H.; Song, L.; Peng, X. Oncogenic miR-210-3p promotes prostate cancer cell EMT and bone metastasis via NF-kB signaling pathway. Mol. Cancer 2017, 16, 117. [CrossRef] [PubMed]

116. Xiao, H.; Shi, J. Exosomal circular RNA_400068 promotes the development of renal cell carcinoma via the miR-210-5p/SOCS1 axis. Mol. Med. Rep. 2020, 6, 4810-4820. [CrossRef]

117. Chen, R.; Li, D.; Zheng, M.; Chen, B.; Wei, T.; Wang, Y.; Li, M.; Huang, W.; Tong, Q.; Wang, Q. FGFRL1 affects chemoresistance of small-cell lung cancer by modulating the PI3K/Akt pathway via ENO1. J. Cell. Mol. Med. 2020, 24, 2123-2134. [CrossRef] [PubMed]

118. Liu, Q.; Hu, S.; Li, X.; Yan, S.; Tan, H. MiRNA-495 inhibits cell proliferation and invasion abilities in gastric cancer cells by down-regulation of FGFRL1. Int. J. Clin. Exp. Pathol. 2016, 9, 7867-7877.

119. Tai, H.; Wu, Z.; Sun, S.; Zhang, Z.; Xu, C. FGFRL1 Promotes Ovarian Cancer Progression by Crosstalk with Hedgehog Signaling. J. Immunol. Res. 2018, 2018, 1-11. [CrossRef]

120. Costales, M.G.; Haga, C.L.; Velagapudi, S.P.; Childs-Disney, J.L.; Phinney, D.G.; Disney, M.D. Small Molecule Inhibition of microRNA-210 Reprograms an Oncogenic Hypoxic Circuit. J. Am. Chem. Soc. 2017, 139, 3446-3455. [CrossRef]

121. Kelly, T.J.; Souza, A.L.; Clish, C.B.; Puigserver, P. A hypoxia-induced positive feedback loop promotes hypoxia-inducible factor 1alpha stability through miR-210 suppression of glycerol-3-phosphate dehydrogenase 1-like. Mol. Cell. Biol. 2011, 31, $2696-2706$. [CrossRef]

122. Cheng, H.H.; Mitchell, P.S.; Kroh, E.M.; Dowell, A.E.; Tewari, M. Circulating microRNA Profiling Identifies a Subset of Metastatic Prostate Cancer Patients with Evidence of Cancer-Associated Hypoxia. PLoS ONE 2013, 8, e69239. [CrossRef] [PubMed]

123. Wei, J.; Gou, Z.; Wen, Y.; Luo, Q.; Huang, Z. Marine compounds targeting the PI3K/Akt signaling pathway in cancer therapy. Biomed. Pharmacother. 2020, 129, 110484. [CrossRef]

124. Zhou, Z.; Yao, B.; Zhao, D. Runx3 regulates chondrocyte phenotype by controlling multiple genes involved in chondrocyte proliferation and differentiation. Mol. Biol. Rep. 2020, 47, 5773-5792. [CrossRef] [PubMed]

125. Chen, X.; Deng, Y.; Yi, S.; Zhu, W.; Weng, G. Loss of expression rather than cytoplasmic mislocalization of RUNX3 predicts worse outcome in non-small cell lung cancer. Oncol. Lett. 2018, 15, 5043-5055. [CrossRef] [PubMed]

126. Li, Z.B.; Chen, X.; Yi, X.J. Tumor promoting effects of exosomal microRNA-210 derived from lung cancer cells on lung cancer through the RUNX3/PI3K/AKT signaling pathway axis. J. Biol. Reg. Homeost. Agents 2021, 35, 473-484.

127. Yang, F.; Yan, Y.B.; Yang, Y.; Xuan, H.; Wang, M.; Yang, Z.Y.; Liu, B.G.; Ye, L.G. MiR-210 in exosomes derived from CAFs promotes non-small cell lung cancer migration and invasion through PTEN/PI3K/AKT pathway. Cell. Sig. 2020, 73, 109675. [CrossRef]

128. Chen, Q.; Zhang, H.Y.; Zhang, J.Y.; Shen, L.; Yang, J.; Wang, Y.; Ma, J.X.; Zhuan, B. miR-210-3p Promotes Lung Cancer Development and Progression by Modulating USF1 and PCGF3. OncoTargets Ther. 2021, 14, 3687. [CrossRef]

129. Kim, K.C.; Yun, J.; Son, D.J.; Kim, J.Y.; Jung, J.K.; Choi, J.S.; Kim, Y.R.; Song, J.K.; Kim, S.Y.; Kang, S.K.; et al. Suppression of metastasis through inhibition of chitinase 3-like 1 expression by miR-125a-3p-mediated up-regulation of USF1. Theranostics 2018, 16, 4409. [CrossRef]

130. Hu, Y.; Cheng, Y.; Jiang, X.; Zhang, Y.; Wang, H.; Ren, H.; Xu, Y.; Jiang, J.; Wang, Q.; Su, H.; et al. PCGF3 promotes the proliferation and migration of non-small cell lung cancer cells via the PI3K/AKT signaling pathway. Exp. Cell Res. 2021, 400, 112496. [CrossRef] [PubMed]

131. Wang, H.; Wang, L.; Zhou, X.C.; Luo, X.Y.; Liu, K.; Jiang, E.H.; Chen, Y.; Shao, Z.; Shang, Z.J. OSCC exosomes regulate miR-210-3p targeting EFNA3 to promote oral cancer angiogenesis through the PI3K/AKT pathway. BioMed Res. Int. 2020, 2125656. [CrossRef]

132. Brew, K.; Nagase, H. The tissue inhibitors of metalloproteinases (TIMPs): An ancient family with structural and functional diversity. Biochim. Biophys. Acta BBA Mol. Cell Res. 2010, 1803, 55-71. [CrossRef] [PubMed] 
133. Murphy, G. Tissue inhibitors of metalloproteinases. Genome Biol. 2011, 12, 233. [CrossRef] [PubMed]

134. Ilie, M.; Lassalle, S.; Long-Mira, E. In papillary thyroid carcinoma, TIMP-1 expression correlates with BRAF (V600E) mutation status and together with hypoxia-related proteins predicts aggressive behavior. Virchows Arch. 2013, 463, 437-444. [CrossRef] [PubMed]

135. Pesta, M.; Kulda, V.; Kucera, R.; Pesek, M.; Topolcan, O. Prognostic Significance of TIMP-1 in Non-small Cell Lung Cancer. Anticancer Res. 2011, 31, 4031-4038.

136. Rauvala, M.; Puistola, U.; Turpeenniemi-Hujanen, T. Gelatinases and their tissue inhibitors in ovarian tumors; TIMP-1 is a predictive as well as a prognostic factor. Gynecol. Oncol. 2005, 99, 656-663. [CrossRef]

137. Wang, C.S.; Wu, T.L.; Tsao, K.C.; Sun, C.F. Serum TIMP-1 in gastric cancer patients: A potential prognostic biomarker. Ann. Clin. Lab. Sci. 2006, 36, 23-30.

138. Ylisirni, S.; Hyhty, M.; MKitaro, R.; Pakk, P.; Risteli, J.; Kinnula, V.L.; Turpeenniemi-Hujanen, T.; Jukkola, A. Elevated serum levels of type I collagen degradation marker ICTP and tissue inhibitor of metalloproteinase (TIMP) 1 are associated with poor prognosis in lung cancer. Clin. Cancer Res. 2001, 7, 1633-1637.

139. Ylisirniö, S.; Höyhtyä, M.; Turpeenniemi-Hujanen, T. Serum matrix metalloproteinases $-2,-9$ and tissue inhibitors of metalloproteinases -1, -2 in lung cancer-TIMP-1 as a prognostic marker. Anticancer Res. 2000, 20, 1311-1316.

140. Jung, K.K.; Liu, X.W.; Chirco, R.; Fridman, R.; Kim, H. Identification of CD63 as a tissue inhibitor of metallonproteinase-1 interacting cell surface protein. EMBO J. 2006, 25, 3934-3942. [CrossRef]

141. Li, G.Y.; Fridman, R.; Kim, H. Tissue Inhibitor of Metalloproteinase-1 Inhibits Apoptosis of Human Breast Epithelial Cells. Cancer Res. 1999, 59, 6267-6275.

142. Liu, X.W.; Bernardo, M.M.; Fridman, R.; Kim, H. Tissue Inhibitor of Metalloproteinase-1 Protects Human Breast Epithelial Cells Against Intrinsic Apoptotic Cell Death via the Focal Adhesion Kinase/Phosphatidylinositol 3-Kinase and MAPK Signaling Pathway. J. Biol. Chem. 2003, 278, 40364-40372. [CrossRef]

143. Liu, X.W.; Taube, M.E.; Jung, K.K.; Dong, Z.; Kim, H. Tissue Inhibitor of Metalloproteinase-1 Protects Human Breast Epithelial Cells from Extrinsic Cell Death: A Potential Oncogenic Activity of Tissue Inhibitor of Metalloproteinase-1. Cancer Res. 2005, 65, 898-906.

144. Taube, M.E.; Liu, X.W.; Fridman, R.; Kim, H. TIMP-1 regulation of cell cycle in human breast epithelial cells via stabilization of p27KIP1 protein. Oncogene 2006, 25, 3041. [CrossRef]

145. Mok, T.S.; Wu, Y.L.; Ahn, M.J.; Garassino, M.C.; Kim, H.R.; Ramalingam, S.S.; Shepherd, F.A.; He, Y.; Akamatsu, H.; Theelen, W. Osimertinib or Platinum-Pemetrexed in EGFR T790M-Positive Lung Cancer. N. Engl. J. Med. 2017, 376, 629-640. [CrossRef] [PubMed]

146. Soria, J.C.; Ohe, Y.; Vansteenkiste, J.; Reungwetwattana, T.; Chewaskulyong, B.; Lee, K.H.; Dechaphunkul, A.; Imamura, F.; Nogami, N.; Kuratal, T. Osimertinib in Untreated EGFR-Mutated Advanced Non-Small-Cell Lung Cancer. N. Engl. J. Med. 2018, 378, 113. [CrossRef]

147. Leonetti, A.; Sharma, S.; Minari, R.; Perego, P.; Tiseo, M. Resistance mechanisms to osimertinib in EGFR-mutated non-small cell lung cancer. Br. J. Cancer 2019, 121, 1-13. [CrossRef]

148. Anke, N.; Hannah, T.; Julie, A.; Alexandra, P.; Luke, G.; Amy, L.; Bundy, J.G.; Tomoyoshi, S.; Aisha, J.; David, P. Remodelling of microRNAs in colorectal cancer by hypoxia alters metabolism profiles and 5-fluorouracil resistance. Hum. Mol. Genet. 2017, 26, 1552.

149. Runglawan, S.; Yingpinyapat, K.; Suyanee, T.; Watcharin, L.; Anchalee, T.; Piti, U.; Narong, K.; Puangrat, Y.; Yang, J.H.; Hee, K.N. Potential role of HIF-1-responsive microRNA210/HIF3 axis on gemcitabine resistance in cholangiocarcinoma cells. PLoS ONE 2018, 13, e199827.

150. Yang, Z.; Zhao, N.; Cui, J.; Wu, H.; Xiong, J.; Peng, T. Exosomes derived from cancer stem cells of gemcitabine-resistant pancreatic cancer cells enhance drug resistance by delivering miR-210. Cell. Oncol. 2020, 43, 123-136. [CrossRef]

151. Kerr, E.M.; Martins, C.P. Metabolic rewiring in mutant Kras lung cancer. FEBS J. 2018, 285, 28-41. [CrossRef] [PubMed]

152. Shen, H.; Che, K.; Lei, C.; Wei, D.; Du, J. Diagnostic and prognostic value of blood samples for KRAS mutation identification in lung cancer: A meta-analysis. Oncotarget 2017, 8, 36812-36823. [CrossRef] [PubMed]

153. Vasan, N.; Boyer, J.L.; Herbst, R.S. A RAS Renaissance: Emerging Targeted Therapies for KRAS-Mutated Non-Small Cell Lung Cancer. Clin. Caner Res. 2014, 20, 3921-3930. [CrossRef] [PubMed]

154. Petanidis, S.; Domvri, K.; Porpodis, K.; Anestakis, D.; Zarogoulidis, K. Inhibition of kras-derived exosomes downregulates immunosuppressive BACH2/GATA-3 expression via RIP-3 dependent necroptosis and miR-146/miR-210 modulation ART ICLE IN FO. Biomed. Pharmacother. 2020, 122, 109461. [CrossRef]

155. Luo, W.B.; Hu, H.X.; Ryan, C.; Zhong, J.; Matthew, K.; Robert, O.M.; Robert, N.C.; Pandey, A.; Semenza, G.L. Pyruvate kinase M2 is a PHD3-stimulated coactivator for hypoxia-inducible factor 1. Cell 2011, 145, 732-744. [CrossRef] 